\title{
ESTIMATING AND ANALYZING THE FACTORS AFFECTING THE PRODUCTION AND PRODUCTIVITY OF SOME CASH CEREAL CROPS IN IRAQ AND EGYPT FOR THE PERIOD 1995-2016
}

\author{
Eman Y. Al Najjar ${ }^{1}$, Basim F. AlDouri ${ }^{2}$, Waleed I. Sultan ${ }^{3}$ \\ ${ }^{1,3}$ Agricultural Economy Department/College of Agriculture and Forests/ \\ University of Mosul \\ ${ }^{2}$ Agricultural Economy Extension Department/College of Agriculture /University \\ of Tikrit \\ Email: emanalnjar75@gmail.com
}

\begin{abstract}
This study aims to estimating and analyzing the factors affecting the production and productivity of the main cereal crops in Iraq and Egypt at the period 1995-2016, which are characterized with low production. Three crops were selected, which are wheat, barley and rice. The research was based on a hypothesis that there is a deterioration in the production of the three crops due to some factors that hamper the development of crops production for the period 1995-2016. To verify the hypothesis, the methodology used linking two directions, the descriptive method which depended on the previous studies dealing with the same topic and the quantitative method based on the standard economics methods and techniques. The two stages normal least squares method was used and then interpreting the results of the quantitative method to evaluate the theoretical aspect of the study depending on the economic theory concept. Important conclusions were reached, including: agriculture in Iraq and Egypt is subjected to several limitations with varying effects on its growth. Also, the research reached the important result: the level of the economic agricultural exposure has a negative impact on the quantities of rice produced in Iraq and Egypt, and the researcher recommended adopting a pricing policy that contributes to the product protection and making the local prices of the crops in question approximately the same international prices.
\end{abstract}

Keywords: Grain production, Grain productivity, Iraq, Egypt

Received:8 /10 / 2020, Accepted: 13/12 / 2020

\section{INTRODUCTION}

The agricultural sector occupies is of a great importance in the economies of the countries in general and the economies of the non-oil developing countries in particular. It is considered one of the important economic activities in terms of its contribution to forming the gross domestic product GDP (Arab Monetary Fund ,2019), agriculture has an evident role and impact in the economic development through securing the food needs for individuals, the agricultural sector of various food production such as the food grains crops which one of the most important of the strategic crops due to their nutritious importance and their substantial role in the economic and social development. As the, agricultural sector contributes a fundamental role in providing the cash resources and use them in the basic needs of economic development through the expansion of export crops (cash resources by 
means of expanding the export of the agricultural crops) as the production situation crops (wheat, barley, rice) indicate that the developing countries suffer from a shortage in local offer of these crops as a result of the lack of production capacities for the current period to cover all the needs and uses of these crops (FAO ,2003). The reason behind this problem is due to a number of economic obstacles that restrict the increase of production and productivity of these crops and also due to the misuse of the economic resources, From this standpoint came the research problem .The importance of research comes from the importance of grain crops in general and the importance of the cash crops in particular, as they vital for the food security and for providing the foreign currency. Also, the importance of the economic and natural factors that influence the production and productivity, The research aims to identify the positive-effect and the negative-effect factors, as well to identify the landmarks and indicators of the most important economic factors that affect the production of these crops and identifying the most effective In its production and productivity to make the suitable decisions. So the study hypothesizes that the deterioration in the productivity of the crops wheat, barley and rice for the period 1995-2016 is due a couple of economic factors and there is a variance in the degree of influence on the productivity of grains crops in Included in the study.

\section{The concept of production and productivity Production}

Production is the process of combining various physical inputs immaterial inputs (plans and knowledge) in order to make something for consumption (output). It is the process of creating a product, good or service that has value and contributes to the benefit of individuals( Kotler, et at.,2006). The field of economics that focuses on production is referred to as production theory, which is similar in many of respects to the consumption (or consumer) theory of economics (Sickles, et at .,2019). Productivity is considered a measure for the efficiency through which the economic resources are transformed into goods and services and its effect is reflected in the costs, prices, profits, level of wages and the standards of living( Al Juboori, 2009), productivity it is to translate the relation between the inputs and outputs of the production process from various perspectives and points of view (Singh,et at .,2000). The quantitative change of production, productivity and the area planted with grain crops wheat, barley and rice during the period 1995-2016

From table (1) it is clear that the average production of wheat, barley and rice during the period 1995-2016 were 2238, 346, 574 thousand tons on average, respectively. This production capability was characterized with oscillation between a year and another during the same period, as shown in figures $(1,2,3)$. The local wheat production ranged between a minimum of(854) thousand tons in 1996 and a maximum of (5055) thousand tons in 2014 and so the range is (4201) thousand tons. At the other hand the barley local production was a minimum of (100) thousand tons in 2013 and a maximum of (919) thousand tons in 2008, so the range is (819) thousand tons. While the local production of rice was a minimum of (4.9) thousand tons in 2003 and a maximum of (1092) thousand tons in 2015 and the range was (1087) thousand tons. The reason of increase and decrease in quantities produced because Iraq's reliance on rainfed agriculture for wheat and barley in addition to the increase of risk and uncertainty as more than the half of the areas in the northern regions of the country are planted using the rainfed agriculture and that results in 
oscillation in production. The area planted is viewed as the most influential factor on crops production wheat, barley and rice in Iraq . By studying the quantitative change of the area planted with the above mentioned crops during the period (1995-2016), it is evident from the data in table (1) that the average area planted with wheat, barley, and rice for the same period was 1032, 109 , 1483 thousand hectares respectively, and there is a clear oscillation in the area during (1995-2016), as shown in figures $(1,2,3)$. Therefore, the area for wheat ranged between a minimum of (1077) and a maximum of (2132) thousand hectares respectively for the years 2002 and 2014. Also, it is clear form table (1) that the minimum area and the maximum area recorded for barley in 2007 and 1995 were $(554,1583)$ thousand hectares respectively. While the minimum area for rice was (2.81)in thousand hectares in 2003 and the maximum area was (276). Therefore the range of the area planted with (wheat, barley, rice) was $(1055,1029,273)$ thousand hectares respectively.

Table (1): Quantitative change and the planted areas of some economic indicators of (wheat, barley, rice) crops in Iraq for the period of 1995-2016

\begin{tabular}{|c|c|c|c|c|c|c|c|c|c|}
\hline \multicolumn{3}{|c|}{ Rice } & \multicolumn{3}{|c|}{ Barley } & \multicolumn{3}{|c|}{ wheat } & \multirow[b]{2}{*}{ year } \\
\hline $\begin{array}{l}\text { Productivity } \\
\text { hectare/Tons }\end{array}$ & \begin{tabular}{|c|} 
Area \\
(thousand \\
hectares)
\end{tabular} & $\begin{array}{c}\text { Production } \\
\text { (thousand } \\
\text { tons) }\end{array}$ & $\begin{array}{l}\text { Productivity } \\
\text { hectare/Tons }\end{array}$ & \begin{tabular}{|c|} 
Area \\
(thousand \\
hectares)
\end{tabular} & $\begin{array}{c}\text { Production } \\
\text { (thousand } \\
\text { tons) }\end{array}$ & $\begin{array}{l}\text { Productivity } \\
\text { hectare/Tons }\end{array}$ & $\begin{array}{c}\text { Area } \\
\text { (thousand } \\
\text { hectares) }\end{array}$ & $\begin{array}{c}\text { Production } \\
\text { (thousand } \\
\text { tons) }\end{array}$ & \\
\hline 2.02 & 129.652 & 261.9 & 0.5624 & \multicolumn{2}{|c|}{1583.32890 .465} & 0.76816 & 1185.91 & 910.97 & 1995 \\
\hline 2.352 & 162.755 & 382.8 & .61446 & \multicolumn{2}{|c|}{1389.78853 .966} & 0.67283 & 1269.34 & 854.04 & 1996 \\
\hline 1.9036 & 164.35 & 312.86 & & \multicolumn{2}{|c|}{1168.93712 .366} & 0.76564 & 1425.49 & 1091.42 & 1997 \\
\hline 2.5923 & 109.145 & 282.93 & 0.62022 & \multicolumn{2}{|c|}{1043.63647 .274} & 0.84417 & 1362.28 & 1150 & 1998 \\
\hline 2.3799 & 115.239 & 274.26 & 0.42967 & \multicolumn{2}{|c|}{\begin{tabular}{|l|l|}
999.77 & 429.578 \\
\end{tabular}} & 0.68871 & 1374.62 & 946.71 & 1999 \\
\hline 2.5761 & 151.187 & & & \multicolumn{2}{|c|}{1046.52629 .863} & 1.0 & 1445.5 & 1474.87 & 2000 \\
\hline 2.4915 & 87.69 & 218.48 & & & 4048 & 1487.69 & 1101.6 & 2001 \\
\hline 50.938 & 4.201 & 213.98 & 0.33419 & \multicolumn{2}{|c|}{ 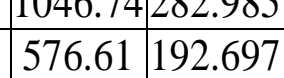 } & 0.96592 & 1077.04 & 1040.33 & 2002 \\
\hline 1.7419 & 2.813 & 9 & 602 & \multicolumn{2}{|c|}{\begin{tabular}{|l|l|}
554.29 & 712.832 \\
\end{tabular}} & & 1304.48 & .45 & 2003 \\
\hline 3.5798 & 54.128 & 193.77 & & \multicolumn{2}{|c|}{\begin{tabular}{|l|l|}
965.53 & 833.437 \\
\end{tabular}} & 1.570 & 1648.74 & .47 & 2004 \\
\hline 2.6555 & 30.621 & 81.32 & 0.80924 & \multicolumn{2}{|c|}{1063.24860 .416} & 1.35894 & 1713.98 & 2329.2 & 2005 \\
\hline 3.1701 & 78.948 & & 136 & \multicolumn{2}{|c|}{\begin{tabular}{|l|l|}
957.31 & 805.445 \\
\end{tabular}} & 985 & 1539.81 & 1832.14 & 2006 \\
\hline & 107.061 & & & \multicolumn{2}{|c|}{1063.32754 .437} & & 1602.67 & & 2007 \\
\hline 2.8919 & 125.641 & 363.34 & 0.89602 & \multicolumn{2}{|c|}{1025.99919 .307} & 1.51059 & 1513.53 & 2286.31 & 2008 \\
\hline 3.1591 & 124.341 & 392.8 & 0.68417 & \multicolumn{2}{|c|}{1093.72748 .291} & 1.40315 & 1569.88 & 2202.78 & 2009 \\
\hline 2.9277 & 84.761 & 248 & & \multicolumn{2}{|c|}{1348.76403 .999} & 0.87437 & 1435.29 & 1254.98 & 2010 \\
\hline 4.2606 & 78.576 & 334.78 & 3227 & 643 & \begin{tabular}{|l|}
728.05 \\
\end{tabular} & 2.54198 & 1435.89 & 3650 & 2011 \\
\hline 4.5266 & 79.75 & 361 & 1.13227 & 643 & 728.051 & 2.08852 & 1728.5 & 3610 & 2012 \\
\hline 6.5729 & 96 & 631 & 0.08407 & 1193 & 100.3 & 2.26573 & 1844 & 4178 & 2013 \\
\hline 5.0852 & 79.25 & 403 & 0.11576 & 1104 & 127.8 & 2.37101 & 2132 & 5055 & 2014 \\
\hline 3.9565 & 276 & 1092 & 0.11576 & 1104 & 127.8 & 2.10204 & 1258.3 & 2645 & 2015 \\
\hline 2.2021 & 276.1 & 608 & 0.11515 & 1104.67 & 127.2 & 3.57538 & 1283.5 & 4589 & 2016 \\
\hline 13.13 & 22719.13 & 12616.56 & 116.86 & 2418.21 & 7609.7 & 32.41 & 32638.44 & 49232.43 & Total \\
\hline 0.600 & 1032086 & 573.51 & 5.31 & 109.91 & 345.89 & 1.47 & 1483.57 & 2237.84 & Average \\
\hline 1.21 & 1029.03 & 819.01 & 49.19 & 273.28 & 1087 & 2.90 & 1055 & 4201 & Range \\
\hline
\end{tabular}


Source. League of Arab States, Arab Organization for development and Agriculture, Annual book for agricultural statistics, vols. $(26,27,28,29)$

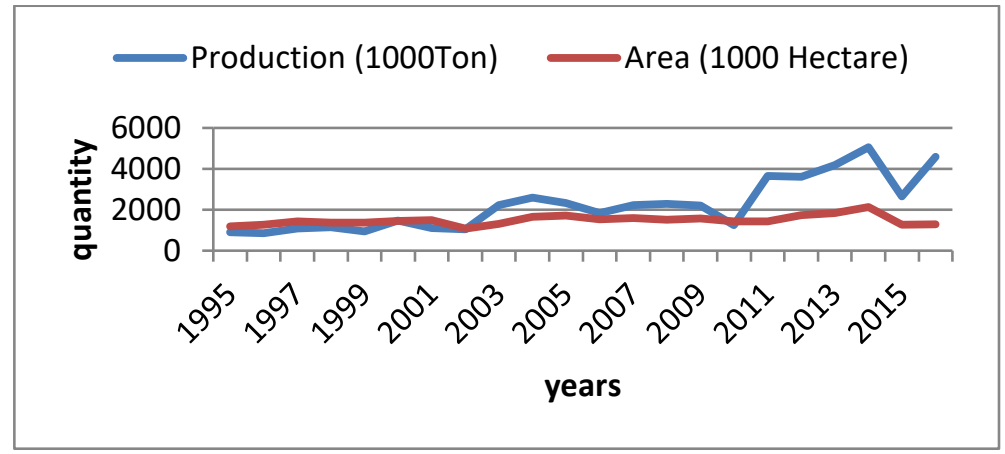

Figure (1): The quantitative change of production and the area planted for wheat for the period 1995-2016 in Iraq.

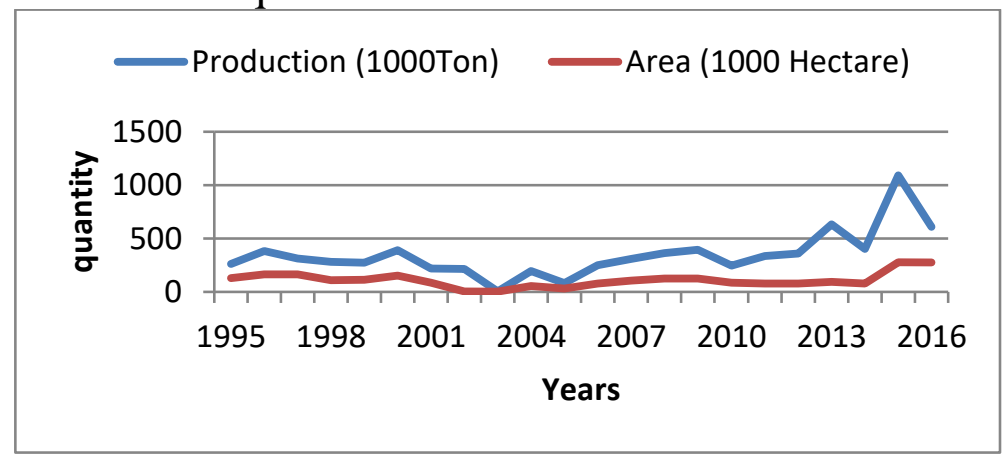

Figure (2): The quantitative change of the production and the area planted for barley for the period 1995-2016 in Iraq

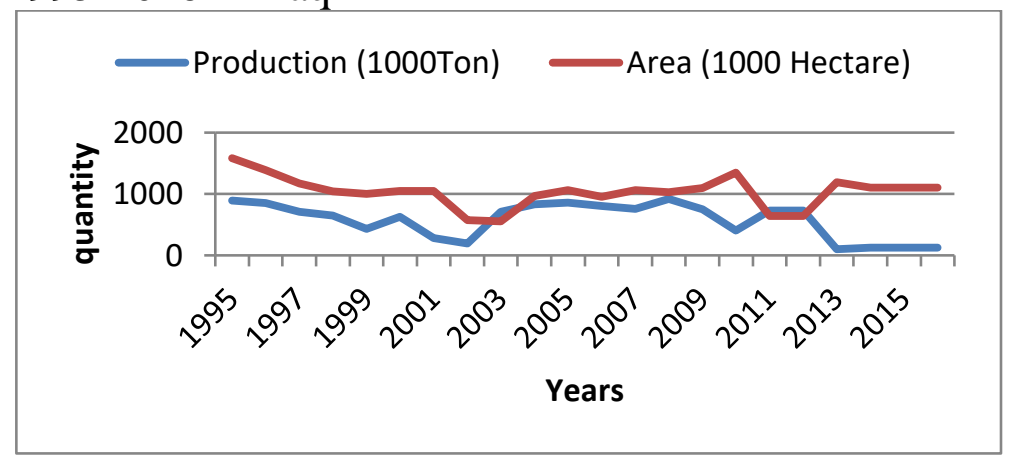

Figure (3): The quantitative change of the production and the area planted with rice for the period 1995-2016 in Iraq.

The productivity of the area unit is regarded as an important indicator used in identifying the degree efficiency of using the modern scientific techniques in agriculture and the productivity of the hectare for (wheat, barley, rice), as table (1) shows were of the average $(1.473,5.31,0.600)$ ton/hectare respectively, so there is a clear oscillation of the hectare yield, as the minimum and maximum of wheat crop was $(0.673,3.575)$ ton/hectare for the years 1996 and 2016 respectively. While the minimum and the maximum for barley was $(0.08,1.29)$ ton/hectare respectively for the years 2003 and 2013. As for rice, the minimum and the maximum, it is clear from the same table that the same productivity quantity varies from one year to another during the period (1995-2016), as the minimum quantity was (1.74) ton/hectare in 
2003, while the maximum quantity was (6.57) ton/hectare in 2013. So, the range of (wheat, barley , rice) productivity is $(2.902,49.19,1.21)$ ton/hectare respectively.

There are important studies conducted in this domain like study. the study of (Mohamed, 2006) about the analysis of the local production, it was concluded that the improvement and increasing the productivity has an effect on production increase of the wheat crop area is $22.98 \%$ which stands for a decreased by means of introducing the recent biological, mechanical and chemical technologies that elevate the crops productivity. In their study,( Brown, et al. ,2020) indicated showed some determinants of the agricultural production in Nigeria. The objective was to determine the effect of the government finance, agricultural credit/Agricultural loan and the price of exchange on the agricultural production. The study was conducted depending on the time series data 1980-2014, which was obtained from the statistical bulletins CBN and NBS. The ordinary least squares method (OLS) was used to identify the relationship amongst the basic variables included by the study. The result of the analysis demonstrated that agricultural financing and agricultural credit/agricultural loan in addition to the exchange price have a positive effect on the agricultural production. In light of the results the researchers reached, the government should offer agricultural credit/agricultural loans to the agricultural sector and that the monitary policy of the government should be carefully designed and that the government has to stabilize the exchange price to encourage the export of the agricultural products. Chatta, ( 2010 ) conducted a study in Punjab region in Pakistan during 2006-2007 to determine the most important factors that impact wheat production in the various crops area in Punjab region. A random sample of 200 wheat farmers was selected to estimate the effect of the factors that influence wheat production, which include: time of planting, seed average, awareness, using of fertilizers, irrigation water quantity and area of the land. All the effects of the factors in question were investigated by using the multi regression analysis. Cobb Douglas function was estimated by using the least square method. The study concluded that most of the factors studied contribute positively to the increase of the produced quantity of wheat with statistical significance. The researcher recommended that the awareness system should focus on educating the farmers more concerning the fight of weeds and applying the suitable amounts of seeds and nitrogen fertilizers.

The study of ( Al Awadh, 2017) dealt with estimating the wheat production function in Al Jazeera area in Sudan at the period 1990- 2014 by using the multiple regression model. The problem was represented by the oscillation of wheat production, and whether the area planted and the production costs have an effect in the production. The hypothesis of the study was that there is a positive relationship between the area planted and the wheat quantity produced and an inverse relation between the costs of production and the wheat quantity produced. The study concluded that there is a direct relation between the areas planted and production ,there is an inverse relation between the production costs and the productivity. the study recommendations of which is increasing the areas planted with wheat, encouraging the farmers by the government to increase the production by means of elevating the wheat price, providing the production inputs and the necessary funding at the right time. Al Mashhadani, (2018) conducted a study about the most important factors that affect the production and consumption of wheat. The research depended 
on the hypothesis that the oscillation in wheat production is associated with an increase in the quantities consumed due to several economic factors. In its methodology, the study incorporated the descriptive and the quantitative methods based on the standard economics and its styles. It used the two-stage least square method. The research reached important conclusions, such as: the crop production encounters an oscillation during the period of the study as a result of oscillation in the donum productivity. So, the researcher recommends using modern agricultural technologies that increase the productivity per donum .

\section{MATERIALS AND METHODS}

The research depends on the estimation and analysis of factors affecting the production and productivity of the selected grain crops. In order to prove the research hypothesis that stipulates that the deterioration in the production of the grain crops and its productivity is caused by economic factors during the period 1995-2016. Several standard models were used, which can confirm this hypothesis in a way that reflects the theoretical framework of the economic problem in question, i.e. representing the relationship between the production, productivity and the factors that affect them.. The economic theory represents the foundation for building the standard models, and these models, in turn, aim at testing the validity of these hypotheses by manifesting the impact of the independent variables on the dependent variable using the numerical values obtained, which help the economic decision makers Determination the future policy (Al Seifou, 2006). The standard model has several stages. The description of the model is considered the first stage. After that come the stages of estimation, testing, applying and prediction. The first step of the model description and formulation is identifying the total internal variables of the model. In this research, the Tow Stage Least Square (Kazem ,2005), method was used.

\section{The first stage of the analysis}

First: the dependent variable: the variable of crops productivity (wheat, barley, rice) as a dependent variable in the standard model for the first stage.

Second: the independent variables: Several economic factors were depended, which represent the variables independent that affecting the crops productivity included in the estimated model, whose mathematical formula is as follows :

$\mathrm{Y}=\mathrm{f}\left(\mathrm{X}_{1}, \mathrm{X}_{2}, \mathrm{X}_{3}, \mathrm{X}_{4}, \mathrm{X}_{5}\right)$

The above relationship can be formulated in the form of a standard (Al Seifou ,1988 )model as follows:

$Y_{1}=\beta_{0}+\beta_{1} X_{1}+\beta_{2} X_{2}+\beta_{3} X_{3}+\beta_{4} X_{4}+\beta_{5} X_{5}+U i \ldots \ldots$

Where:

$\mathrm{Y}_{1}$ : Crops productivity (wheat, barley, rice) $(\mathrm{Kg} /$ hectare)

$\mathrm{X}_{1}$ : the share of each hectare of the agricultural labor (Man / day).

$\mathrm{X}_{2}$ : Mechanical technology (1000 horse).

$\mathrm{X}_{3}$ : Chemical technology (1000 tons).

$\mathrm{X}_{4}$ : Nominal protection coefficient (the net).

$\mathrm{X}_{5}$ : The local price of the previous year (dollar).

$\beta_{0}$ : intercept term

$\beta_{1}, . ., \beta_{5}$ : Independent variables coefficients.

Ui: The random variable . 


\section{The second stage of the analysis}

First: the dependent variable: the production quantity of the crops (wheat, barley, rice) was depended as a dependent variable in the standard model for the second stage of the analysis.

Second: the independent variables: Several economic factors were depended, variables that affect the production quantity of the Cereal crops under investigation in the estimated model, whose mathematical formula is as follows:

$\mathrm{Y}_{2}=\mathrm{F}\left(\mathrm{X}_{1}, \mathrm{X}_{2}, \mathrm{X}_{3}, \mathrm{X}_{4}, \mathrm{X}_{5}, \mathrm{X}_{6}\right)$

The above relationship can be formulated in the form of a standard model as follows:

$Y_{2}=\beta_{0}+\beta_{1} X_{1}+\beta_{2} X_{2}+\beta_{3} X_{3}+\beta_{4} X_{4}+\beta_{5} X_{5}+\beta_{6} X_{6}+U_{1}$

Where:

$\mathrm{Y}_{2}$ : Crops production (wheat, barley, rice) in the selected countries (ton).

$\mathrm{X}_{1}$ : The estimated productivity $\left(\hat{Y}_{1}\right)$ from the first equation (ton).

$\mathrm{X}_{2}$ : The planted area (Hectare).

$\mathrm{X}_{3}$ : Size of the local demand (quantities available for consumption) (ton).

$\mathrm{X}_{4}$ : Economic exposure (average of agricultural economic exposure).

$\mathrm{X}_{5}$ : International price of the crops (dollar).

$\mathrm{X}_{6}$ : Size of the agricultural loans (million dollars).

The research involved a time series of twenty-two years in 1995-2016and it employed the multiple linear regression using the two-stage least square method.

\section{RESULTS AND DISCUSSION}

First: Quantitative analysis results of the effect of independent variables in the productivity of wheat, barley and rice in Iraq between 1995-2015 Table 2

Table (2): Productivity indicators crops (wheat, barley, rice) in Iraq during the period $1995-2016$

\begin{tabular}{|c|c|c|c|c|c|c|}
\hline crop/Wheat & $\mathrm{Xi}$ & $\mathrm{X} 1$ & $\mathrm{X} 2$ & $\mathrm{X} 3$ & $\mathrm{X} 4$ & $\mathrm{X} 5$ \\
\hline $\mathrm{R}^{2}: 81.72$ & $\beta \mathrm{i}$ & -0.495 & 0.211 & 1.0211 & 0.418 & -0.161 \\
\hline $\mathrm{R}^{-2}: 71.22$ & $t^{*}$ & -1.90 & 0.72 & 3.04 & 2.87 & -1.91 \\
\hline $\mathrm{F}: 8.04$ & Function & \multirow{2}{*}{\multicolumn{5}{|c|}{ Double Logarithmic }} \\
\hline D. $W: 1.97$ & type & & & & & \\
\hline crop /barely & $\mathrm{Xi}$ & $\mathrm{X} 1$ & $\mathrm{X} 2$ & $\mathrm{X} 3$ & $\mathrm{X} 4$ & $\mathrm{X} 5$ \\
\hline $\mathrm{R}^{2}: 73.51$ & $\beta \mathrm{i}$ & -0.530 & -1.676 & 0.567 & 0.211 & 0.046 \\
\hline $\mathrm{R}^{-2}: 61.35$ & $t^{*}$ & -2.11 & -2.99 & 3.57 & 1.86 & 0.39 \\
\hline $\mathrm{F}: 4.4$ & \multirow{2}{*}{$\begin{array}{c}\text { Function } \\
\text { type }\end{array}$} & \multirow{2}{*}{\multicolumn{5}{|c|}{ Double Logarithmic }} \\
\hline D. $W: 1.98$ & & & & & & \\
\hline crop /Rice & $\beta \mathrm{i}$ & $\mathrm{X} 1$ & $\mathrm{X} 2$ & $\mathrm{X} 3$ & $\mathrm{X} 4$ & $\mathrm{X} 5$ \\
\hline $\mathrm{R}^{2}: 65.11$ & $\mathrm{Xi}$ & 0.233 & 0.162 & -0.388 & -0.100 & 0.110 \\
\hline $\mathrm{R}^{-2}: 45.51$ & $t^{*}$ & 1.74 & 0.36 & -2.75 & -1.46 & 1.12 \\
\hline F: 3.43 & \multirow{2}{*}{$\begin{array}{c}\text { Function } \\
\text { type }\end{array}$} & \multirow{2}{*}{\multicolumn{5}{|c|}{ Double Logarithmic }} \\
\hline D. $W: 2.04$ & & & & & & \\
\hline
\end{tabular}

Source: Prepared by the researchers depending on the analysis results for the period 1995-2016 
The results in table (2) indicate the significance of hectare share variable of agricultural work X1 concerning positive effect in the Productivity of rice with a flexibility of $0.233^{(*)}$ units and this value means that the increase in agricultural work by $1 \%$ leads to an increase in rice production by $0.233 \%$ units, whereas, the abstract negative effect of the hectare share variable of agricultural work has come to affect the production of wheat and barley crops with flexibility of $0.495^{(* *)}, 0.530$ units respectively and the negative sign of these two variables means that the increase in agricultural work force employed in both crops by $1 \%$ leads to a decrease in production by $0.495 \%, 0.530 \%$ and this reason for this is not attributed with the economic theory norms; the reason behind that is seasonal unemployment of agricultural workers, besides, the production of the wheat and barley crops is usually done by using high technological density which has a negative impact of this variable with the reliable variable. The results of the aforementioned table showed the significance of the mechanical technology variable X2, show negative effect in the barley crop with flexibility of 1.676 unit and this value means that the increase of mechanical technology by $1 \%$ leads to a decrease in the productivity of barley crop by $1.676 \%$ units; and this result does not coincide with the economic theory norms and that is due to the non-utilization of agricultural technological means in the production of the already mentioned crop in an ideal way. This is reflected in making this variable do not participate in the productivity of the already mentioned crop, the abstractness of this variable was not significant the effect on the productivity of the wheat and rice crops. The reason for this is the lack of use of this type of technology about the wheat crop, especially in lands that are almost guaranteed rain and not guaranteed rain, and with regard to the rice crop, most of its agricultural work depends on manual labor (United Nation 1987-1988).

The estimation results showed that chemical technology X3 in positive effect on the productivity of wheat and barley crops with flexibility of 1.021 and 0.567 units respectively and this result means that the increase in chemical technology by $1 \%$ leads to an increase in the production of the two mentioned crops by $1.021 \%, 0.567 \%$ units respectively and this result coincides with the economic theory norms; the production of cash crops increases with every increase in chemical technology, whereas the abstract negative effect of the chemical technology variable has emerged to affect the productivity of the rice crop with flexibility of 0.388 units and the negative sign of the signal of this variable means that increasing chemical technology by $1 \%$ leads to a decrease in the productivity of the rice crop by $0.388 \%$ units, the reason behind that is the farmers' ignorance of this crop and they cannot determine the optimal blending of the chemical fertilizers that are required in increasing the production of this crop. The results of the positive analysis of the variable of nominal protection coefficient X4 are shown in affecting the production of the wheat and barley crops with flexibility of 0.418 and 0.212 units respectively and these values mean that the $1 \%$ increase of the protection coefficient leads to increasing the production of the aforementioned crops by $0.418 \%$ and $0.212 \%$ respectively and this result coincides with the economic theory norms which means that the state provides

$\left({ }^{*}\right)$ flexibilities in double logarithm functions are calculated as :ep $=\mathrm{Bi}$

$\left({ }^{* *}\right)$ flexibilities in linear functions are calculated as: ep $=\mathrm{Bi} \frac{\bar{x}}{\bar{y}}$ 
support for the inputs and outputs of both crops which has been reflected by an increase in their Productivity, While the estimation results showed that the nominal protection coefficient variable $\mathrm{X} 4$ was not significant the effect on the productivity of the rice crop, and this result means that the state does not grant subsidies or any kind of incentives to farmers of this (Al Wasiti, et at ., 2003). The results of the negative impact analysis of the local price variable of the wheat crop for a former year X5 are shown in the effect on the productivity of the already mentioned crop with flexibility of 0.161 unit, and this value means that the local price of the wheat crop of a former year $1 \%$ decreases the productivity of the already mentioned crop by $0.161 \%$, which does not coincide with the economic theory norms and that is because the prices of the crop have not been satisfying and have not reached the level of the actual prices of this crop the thing that makes this variable does not participate in increasing the productivity of the wheat crop, The estimation results showed that the local price variable X5 was not significant to affect the productivity of the barley and rice crops, as the reason for this lies in the state's purchase of these two crops at prices specified by it in advance, which made this variable not an incentive for farmers to increase the productivity of their lands cultivated with both the rice and barley crops (AL Ezzi , 2000).

Second: Quantitative analysis results of independent variable effect in the production of wheat, barley and rice in Iraq at the period 1995 - 2016 Table (3)

Table (3): Production indicators crops (wheat, barley, rice) in Iraq during the period $1995-2016$

\begin{tabular}{|c|c|c|c|c|c|c|c|}
\hline crop /Wheat & $\mathrm{Xi}$ & $\mathrm{X} 1$ & $\mathrm{X} 2$ & X3 & $\mathrm{X} 4$ & $\mathrm{X} 5$ & X6 \\
\hline $\mathrm{R}^{2}: 90.02$ & $\beta \mathrm{i}$ & 5.945 & 0.815 & 0.223 & -0.016 & 0.179 & 0.054 \\
\hline $\mathrm{R}^{-2}: 83.12$ & $\mathrm{t}^{*}$ & 6.13 & 3.83 & 1.99 & -1.7 & 0.82 & 2.16 \\
\hline$\frac{F: 20.15}{D-W: 2.09}$ & $\begin{array}{l}\text { Function } \\
\text { type }\end{array}$ & \multicolumn{6}{|c|}{ Double Logarithmic } \\
\hline crop /barely & $\mathrm{Xi}$ & $\mathrm{X} 1$ & $\mathrm{X} 2$ & X3 & X4 & X5 & X6 \\
\hline $\mathrm{R}^{2}: 41.93$ & $\beta \mathrm{i}$ & 4.188 & 0.910 & 0.843 & -0.006 & -0.171 & -0.016 \\
\hline $\mathrm{R}^{-2}: 20.93$ & $\mathrm{t}^{*}$ & 1.79 & 2.50 & 1.57 & 0.14 & -0.26 & -1.09 \\
\hline $\begin{array}{c}F: 2.14 \\
D-W: 2.84\end{array}$ & $\begin{array}{c}\text { Function } \\
\text { type }\end{array}$ & \multicolumn{6}{|c|}{ Double Logarithmic } \\
\hline crop /Rice & $\mathrm{Xi}$ & X1 & $\mathrm{X} 2$ & $\mathrm{X} 3$ & $\mathrm{X} 4$ & $\mathrm{X5}$ & $\mathrm{X6}$ \\
\hline $\mathrm{R}^{2}: 80.83$ & $\beta \mathrm{i}$ & 10.244 & 0.60 & 0.568 & -0.092 & 0.219 & 0.060 \\
\hline $\mathrm{R}^{-2}: 76.45$ & $\mathrm{t}^{*}$ & 1.70 & 3.93 & 2.98 & -2.64 & 1.86 & 1.18 \\
\hline \begin{tabular}{|c|}
$\mathrm{F}: 12.73$ \\
$\mathrm{D}-\mathrm{W}: 1.99$
\end{tabular} & $\begin{array}{c}\text { Function } \\
\text { type }\end{array}$ & \multicolumn{6}{|c|}{ Double Logarithmic } \\
\hline
\end{tabular}

Source: prepared by the researchers depending on the quantitative analysis results for the period 1995-2016

The results of table (3) showed the estimated productivity variable X1 the positive effect in the produced quantities of the wheat, barley and rice crops with flexibility of $5.945,4,188,10.244$ units respectively and these values mean that the 
increase in the mentioned crops by $1 \%$ leads to increasing the produced quantities in which by $\% 5.945, \% 4,188$, and $\% 10.244$ units and this is a logical result coinciding with the discipline of the economic theory which holds that the relationship between the two variable is direct. This means that the farmers of these crops rely on horizontal expansion methods via increasing the cultivated area and vertical expansion using valuable inputs and improved kinds that participated in increasing the quantities produced for their importance in satisfying the local consumption and export. In the same table, the positive results of the cultivated area variable X2 have shown the effect on the produced quantities of the already mentioned crops with flexibility of $0.815,0.910,0.605$ units respectively. These values mean that the increase in the cultivated area $1 \%$ leads to increasing the produced quantities of the three crops by $0.815 \%, 0.910 \%, 0.605 \%$ units respectively. This result coincides with the discipline of the economic theory which holds that the increase in the cultivated area with cash crops participates in increasing the produced quantities of these crops which signals the importance of horizontal expansion in producing the crops under study. The estimation results showed the positive effect of local demand variable X3 of the produced quantities of the wheat and rice crops with flexibility of $0.223,0.568$ units and these values indicate that the increasing local demand on both crops by $1 \%$ leads to an increase in the produced quantities of these crops by $0.223 \%$ and $0.568 \%$ units respectively. This result coincides with the economic theory norms which hold in principle that the increase in the local demand on cash crops results in an increase in the quantities of these crops. The estimation results showed that the local demand variable $\mathrm{X}_{3}$ was insignificant in terms of barley production and that is due to the limited demand on this crop as it is used as fodder for animals and also used in some pharmacological industries(Yasin ,et al.,1998).

The results of estimation showed negative of the variable of agricultural economic exposure $\mathrm{X} 4$ show the effect of the produced quantities of the wheat and rice crops with flexibility of 0.016 and 0.092 units respectively. These values mean that the increase in the average of the agricultural economic cover by $1 \%$ leads to a decrease in the produced quantities of both crops by $0.016 \%$ and $0.092 \%$ units respectively. This result coincides with the norms of the economic theory which holds in principle that the opening towards the outside world makes the imported product compete its local counterpart for being cheaper and of a better quality so, the consumer ignores the local product which is reflected on decreasing the motives for producing these crops in local farmers making the produced quantities less than before. Also, the estimation results showed that the variable of the agricultural economic exposure $\mathrm{X} 4$ in insignificant in terms of affecting barley production and this is a normal result because of the competition of the counterpart foreign product, which is characterized with better quality and lower prices in addition to the consumer's tendency to pferer purchasing the imported barley instead of the local one(AlTaee,2015). The results in table (3) show positive abstractness of the variable of the international price of the crop X5 in affecting the produced quantities of the rice crop with flexibility of $0.219 \%$ units and this value means that the increase of the international price of rice by $1 \%$ leads to increasing the produced quantities of this crop by $0.219 \%$ units which is a logical result that coincides with the norms of the economic theory; the increase in the international price of the crop is considered a 
positive factor that has an effect on the produced quantities of the crop in question due to the increase in the exported quantities of it to the international markets, especially the Iraqi rice is regarded as one of the most excellent types of rice around the world which is increasingly demanded by foreign countries .Estimation Results indicated that the effect of the international price X5 concerning wheat and barley production is statistically insignificant because the production of the two crops does not meet the local demand. Therefore, any change in wheat and barley international prices does not influence the quantities produced for both the crops and this shows the insignificancy of this variable(Al Najafi,et at., 2010). The abstract positive estimation results of the agricultural loan variable X6 have shown the effect on the produced quantities of the wheat crop with flexibility of 0.054 units, and this value coincides with the norms of the economic theory considering that the loans given to farmers by the state help expanding their lands and enable them of using modern agricultural means which participate in increasing the produced quantities of the already mentioned crop. The results of estimation showed that the variable of the agricultural loans size X6 has no significant effect on barley and rice production. The reason behind that is most of the farmers do not use the agricultural loans for the purpose of expanding the scope of their agricultural production compared to the use of loans in other non-agricultural domain and this concealed the effect of this variable in both crops production( Raka,1994).

Three: Quantitative analysis results of the independent variables effect in the productivity of wheat, barley and rice in Egypt at the period 1995-2016 Table (4)

Table (4): Productivity indicators crops (wheat, barley, rice) in Egypt during the period 1995 - 2016

\begin{tabular}{|c|c|c|c|c|c|c|}
\hline crop / Wheat & $\mathrm{Xi}$ & $\mathrm{X} 1$ & $\mathrm{X} 2$ & $\mathrm{X} 3$ & $\mathrm{X} 4$ & X5 \\
\hline $\mathrm{R}^{2}: 88.63$ & $\beta \mathrm{i}$ & 0.018 & 1.061 & 0.586 & -0.042 & 0.308 \\
\hline $\mathrm{R}^{-2}: 85.30$ & $\mathrm{t}^{*}$ & 0.51 & 2.06 & 3.23 & -0.64 & 2.19 \\
\hline $\mathrm{F}: 27.80$ & \multirow{2}{*}{ Function type } & \multirow{2}{*}{\multicolumn{5}{|c|}{ Double Logarithmic }} \\
\hline $\mathrm{D}-\mathrm{W}: 1.77$ & & & & & & \\
\hline crop / barely & $\mathrm{Xi}$ & $\mathrm{X} 1$ & $\mathrm{X} 2$ & X3 & $\mathrm{X} 4$ & $\mathrm{X5}$ \\
\hline $\mathrm{R}^{2}: 70.86$ & $\beta \mathrm{i}$ & 0.183 & -2.167 & 0.613 & -0.085 & -0.627 \\
\hline $\mathrm{R}^{-2}: 65.35$ & $\mathrm{t}^{*}$ & 2.23 & -2.35 & 2.19 & -0.42 & -1.73 \\
\hline $\mathrm{F}: 7.4$ & \multirow{2}{*}{ Function type } & \multirow{2}{*}{\multicolumn{5}{|c|}{ Double Logarithmic }} \\
\hline$D-W: 2.18$ & & & & & & \\
\hline crop /Rice & $\mathrm{Xi}$ & $\mathrm{X} 1$ & $\mathrm{X} 2$ & X3 & $\mathrm{X} 4$ & $\mathrm{X5}$ \\
\hline $\mathrm{R}^{2}: 69.11$ & $\beta \mathrm{i}$ & -0.239 & 1.765 & 0.408 & 0.017 & 0.219 \\
\hline $\mathrm{R}^{-2}: 45.61$ & $\stackrel{*}{\mathrm{t}}^{2}$ & -1.901 & 2.85 & 1.79 & 0.14 & 1.83 \\
\hline $\mathrm{F}: 4.51$ & \multirow{2}{*}{ Function type } & \multirow{2}{*}{\multicolumn{5}{|c|}{ Double Logarithmic }} \\
\hline $\mathrm{D}-\mathrm{W}: 2.04$ & & & & & & \\
\hline
\end{tabular}

Source prepared by the researchers based on the results of quantitative analysis during the period $1995-2016$ 
The results of table (4) the abstractness of the hectare share variable of agricultural work $\mathrm{X} 1$ in positive effect of the productivity of the barley crop with flexibility of 0.183 units and this value means that the increase in the already mentioned variable by $1 \%$ indicates to an increase in the Productivity of Egyptian barley by $\% 0.183$ units and the positive sign of the parameter of this variable coincides with the norms of the economic theory which maintains that the relation is direct between the mentioned variable and the barley crop productivity, whereas the results of the same table which are abstract and negative of the hectare share variable of agricultural work show the effect in the production of the rice crop with flexibility of 0.239 units and the negative sign means that the increase in the mentioned variable by $1 \%$ leads to a decrease in the production of the rice crop by $0.239 \%$ units but this result does not coincide with the economic theory norms for the rice cultivation happens, as usual, in farms submerged with water and these areas are limited therefore the increase in labor validates the law of diminishing returns which in turn decreases the production of the mentioned crop. Results of the estimation highlighted that the variable of the hectare share of the agricultural labor X1 has no significant effect on wheat productivity.

The reason behind that is attributed to using the machinery on a wide range in most of the agricultural works instead of the human power to the extent that the significance of this variable effect on wheat productivity disappeared(Al Dulaimi,2002), and the results show, in table (4), the abstractness of the mechanical technology variable X2 in positive wheat and rice crops with flexibility of 1.061 and 1.765 units respectively and the positive sign of the parameter of these two crops means that the increase in mechanical technology by $1 \%$ leads to an increase in the production of both of them by $1.06 \%$ and $1.765 \%$ units respectively and it is a logical result that coincides with the norms of the economic theory which maintains the direct relation between mechanical technology and the production of cash crops, whereas results of negative abstract estimation of the mechanical technology variable show the effect in barley crop production with flexibility of 2.167 units and the negative sign of the parameter of this variable means that the increase in the mentioned variable by $1 \%$ leads to a decrease in the production of the barley crop by 2.167 units which is a result that does not coincides with the norms of the economic theory and the reason behind that is the inability of exploiting the means and mechanical technology equipment in cultivating the mentioned crop using sound scientific means and methods which has led to a decrease in the production of the crop in question. The results of positive abstract estimation of the chemical technology variable X3 show the effect in the production of wheat, barley and rice with flexibility of 0.586 , $0.613,0.408$ unit respectively, the positive sign of this parameter means that the increase in chemical technology by $1 \%$ leads to an increase in the production of the mentioned crops by $0.586,0.613,0.408 \%$ respectively .The positive sign of the parameter of this variable means that the increase in chemical technology by $1 \%$ leads to increasing the production of the mentioned crops by $0.586 \%, 0.613 \%, 0.408 \%$ unit respectively, this result coincides with the norms of the economic theory which maintains that the relation between the two variables is direct, whereas the estimation results in table (4), it was clear that the variable of the nominal protection coefficient $\mathrm{X} 4$ had no significant effect on wheat, barley and rice productivity . The reason for 
this lies the Egyptian government does not provide support to this crops farmers to prevent exporting it, or selling it to the neighboring countries, but to use their solely for the local consumption purposes(Al Zawbaee, et al.,1999).The positive abstract estimation results of the local price variable of the crops of a former year X5, show the effect in the productivity of the rice and wheat crops with flexibility of 0.308 , 0.219 unit respectively and the positive sign of the parameter of this variable means that the increase in the value of the mentioned variable by $1 \%$ leads to increasing the productivity of the two crops by $0.308 \%$ and $0.219 \%$ units, the reason behind that , the increase in the prices of the crops is considered impetus to farmers to increase their productivity of these crops, whereas the negative abstract estimation results of the already mentioned variable show the effect in the barley crop productivity with flexibility of 0.627 unit and the negative sign of the parameter of this variable means that the increase in the price of barley of a former year by $1 \%$ leads to decreasing the productivity by $627 \%$ unit . This result does not coincide with the norms of the economic theory, because the price of the former year is less than the price of the present crop the thing that makes no participation of this variable in the increasing of the productivity.

Four: Quantitative analysis results of the independent variables effect in the production of wheat, barley and rice in Egypt for the period 1995-2016, Table (5)

Table (5): Production indicators crops (wheat, barley, rice) in Egypt during the period $1995-2016$

\begin{tabular}{|c|c|c|c|c|c|c|c|}
\hline $\begin{array}{l}\text { Wheat } \\
\text { crop }\end{array}$ & $\mathrm{Xi}$ & $\mathrm{X} 1$ & $\mathrm{X} 2$ & X3 & $\mathrm{X} 4$ & X5 & X6 \\
\hline $\mathrm{R}^{2}: 94.03$ & $\beta \mathrm{i}$ & 1.963 & -0.006 & -0.323 & 0.019 & 0.167 & 4.063 \\
\hline $\mathrm{R}^{-2}: 92.02$ & t & 6.62 & -0.32 & -1.98 & 0.87 & 1.63 & 1.81 \\
\hline $\begin{array}{c}F: 25.16 \\
-W: 1.98\end{array}$ & $\begin{array}{c}\text { Function } \\
\text { type }\end{array}$ & \multicolumn{6}{|c|}{ Double Logarithmic } \\
\hline crop / barely & $\mathrm{Xi}$ & $\mathrm{X} 1$ & $\mathrm{X} 2$ & X3 & $\mathrm{X} 4$ & $\mathrm{X} 5$ & X6 \\
\hline $\mathrm{R}^{2}: 82.78$ & $\beta \mathrm{i}$ & 0.190 & 0.880 & -0.455 & 0.593 & 0.091 & 5.935 \\
\hline $\mathrm{R}^{-2}: 81.25$ & $\mathfrak{t}^{*}$ & 2.75 & 2.39 & -1.81 & 2.14 & 1.87 & 2.89 \\
\hline $\begin{array}{c}\text { F: } 16.34 \\
\text { D- W :2.08 }\end{array}$ & $\begin{array}{c}\text { Function } \\
\text { type }\end{array}$ & \multicolumn{6}{|c|}{ Double Logarithmic } \\
\hline crop /Rice & $\mathrm{Xi}$ & $\mathrm{X} 1$ & $\mathrm{X} 2$ & $\mathrm{X} 3$ & $\mathrm{X} 4$ & $\mathrm{X} 5$ & X6 \\
\hline $\mathrm{R}^{2}: 89.82$ & $\beta \mathrm{i}$ & 0.224 & 0.586 & 0.656 & -0.931 & -0.006 & 5.061 \\
\hline $\mathrm{R}^{-2}: 84.46$ & $\mathrm{t}^{*}$ & 1.42 & 3.94 & 3.56 & -2.82 & -0.07 & 1.90 \\
\hline $\begin{array}{c}F: 18.74 \\
D-W: 1.97\end{array}$ & $\begin{array}{c}\text { Function } \\
\text { type }\end{array}$ & \multicolumn{6}{|c|}{ Double Logarithmic } \\
\hline
\end{tabular}

Source prepared by the researchers based on the results of quantitative analysis during the period $1995-2016$

The results in table (5) show the abstractness of the estimated production variable $\mathrm{X} 1$ in positive effect of the produced quantities of the wheat and barley crops with flexibility of 1.963 and 0.190 units respectively and these values mean that the 
increase in the production of two crops by $1 \%$ leads to an increase in the produced quantities of both of them by $1.963 \%$ and $0.190 \%$ units respectively which is a logical result coinciding with the norms of the economic theory; the agricultural product increases of cash crops increases by the increase in production. The abstractness of this variable has not affected the production of the rice crop and the abstract positive results of the previous table of the cultivated land variable X2 affect the production of the rice and barley crops with flexibility of 0.880 and 0.586 units respectively, these values show that the increase in the area of the cultivated land of $1 \%$ leads to an increase in the produced quantities of both crops by $0.880 \%$ and $0.586 \%$ units. This result coincides with the norms of the economic theory and the cash crops product increases by every increase in the cultivated lands, estimation results indicated that the variable of planted area X2, had no significance effect on wheat production and the reason behind that is that the Egyptian farmers achieved the optimum exploitation of the areas planted with this crop(Al Nei mah,2009). Therefore, the tiny changes in the planted areas did not influence the production of this crop.

The positive abstract estimation results of the variable of the local demand X3 have affected the produced quantities of the rice crop with flexibility of 0.656 units and this value means that the increase in the local demand of Egyptian rice crop $1 \%$ leads to an increase in the produced quantities of it by $0.656 \%$ units and this result coincides with the norms of the economic theory which maintains the direct relation between the two variables. Whereas the negative abstract estimation results of the already mentioned variable have shown the effect in the produced quantities of the crop of wheat and barley with flexibility of 0.323 and 0.455 units respectively and these values mean that the increase in the local demand by $1 \%$ leads to a decrease in the produced quantities of both crops by $0.323 \%$ and $0.455 \%$ units respectively. This value does not coincide with the norms of the economic theory because many of the people living in the countryside have emigrated to urban places the thing that leaves many areas of land uncultivated and unexploited thus increasing the demand of individuals on these two crops and that is why this variable does not participate positively in increasing the produced quantities of both crops.

The positive abstract results of the agricultural economic exposure variable $\mathrm{X} 4$ affect the produced quantities of the barley crop with flexibility of 0.593 units and this value means that the increase in the agricultural economic exposure by $1 \%$ leads to an increase in the produced quantities of the already mentioned crop by $0.593 \%$ units which is a natural result that coincides with the norms of the economic theory which indicates that exposure to the outer world participates in increasing the local demand to meet the needs of the local market with a surplus for export, whereas, the negative abstract effect of the mentioned variable appeared in affecting the produced quantities of the rice crop with flexibility of 0.931 units and this value means that the surplus in the agricultural production by $1 \%$ leads to decreasing the produced quantities of rice by $0.931 \%$ units and the reason is that the exported rice competes with the local rice produced in local farms as to price and quality and this has made the effect of this variable does not participate in the quantities of the produced rice and the variable of the agricultural economic exposure X4 had no significant effect on wheat production. The reason behind that is that Egypt mostly depends on the 
local production of wheat to meet the domestic consumption in stead of relying on importing this crop from the foreign markets(Al Azzawi,2011). The estimation results show the abstractness of the international price variable of the crop X5 in the positive effect in the produced quantities of the barley crop with flexibility of 0.091 units and this value means that the increase in the international price of the barley by $1 \%$ leads to an increase in the produced quantities by $0.091 \%$ units and this result coincides with the economic theory norms and the produced quantities of any crop increases when the international prices increase because the increase in price is regarded an impetus to production increase, the international price variable X5, had no significant effect on wheat and rice production due to the same reason mentioned in the case of the agricultural economic exposure (Al Najafi,et al.,2008). The positive abstract estimation results of the agricultural loans variable X6 affect the produced quantities of the cash crops under study with flexibility of 4.063, 5.935, 5.061 unit respectively, and these values mean that the increase in the agricultural loans values by $1 \%$ leads to an increase in the produced quantities of the crops under study by $4.063 \%, 5.935 \%, 5.061 \%$ unit respectively, which is a logical result that coincides with the economic theory norms. The agricultural product increases when there is an increase in the loans given to farmers considering, that these loans a means that enables the farmer to use modern agricultural technology and high priced inputs and modern types, that participate in increasing the produced quantities of the aforementioned crops.

\section{CONCLUSIONS AND RECOMMENDATIONS}

There is a fluctuation in the quantities produced for wheat, barley and rice, in addition to a fluctuation in the cultivated area during the period of research at the level of Iraq, which led to fluctuation Productivity per unit area For wheat barley and rice. Show the results of the analysis of the function of producing cereal crops (wheat, barley, rice), that the economic-agricultural degree of exposure in Iraq had a negative impact For these crops and this Which contributed to decreasing the production of these crops. Moreover, it was concluded from the study that the pricing policy employed in Iraq had a positive effect on the consumer especially for rice on the levels of satisfaction and benefit and a negative impact on the product on the levels of profits and income. As for the effectiveness of agricultural loans, it had a negative effect for the case of barley and a slight positive effect for wheat and rice and it is thought that the reason behind that was not using the loans in investment but for consumption purposes. The relation between the variable of the hectare share of agricultural labor and the dependent variable of rice crop was positive, but this variable had a negative sign for the crops (wheat, barley) and the reason behind that is the masked unemployment and the unproductive labor which in turn caused productivity decrease. Also, the study showed that there is a positive relation between the mechanical technology variable represented by (harvesters and tractors) with the production of wheat and rice and a negative relation for barley only. The research showed that the degree of economic agricultural exposure Egypt had a positive impact on the production of rice in Egypt. From the result of analysis the effectiveness of loan sizes on the production of the three crops in Egypt between positive and negative as a result of lack of finance resources, and the study also indicated the 
significant relation the hectare share of the agricultural labor and the productivity of the crops wheat, barley and rice in Egypt. The study recommended that the agricultural policies should be directed to the horizontal expansion by means of increasing the lands which is good for cultivation through the reclamation of the unused lands in addition to the capital expansion by through using modern technologies in preparing the production plans, using high-productive seeds, following a pricing policy that protects the product and the consumer, determining the local prices to be as similar as the international prices for the strategic crops and supporting the production requirements, activate the role of the bank of agriculture by means of controlling the agricultural loans to be used in agriculture investment using the directed loaning and connecting loaning to the process of agricultural development, paying more attention to the human resources to be technically and administratively qualified to perform the agricultural work, expanding the use of technologies represented by the mechanical, chemical and biological technologies which are of high productivity.

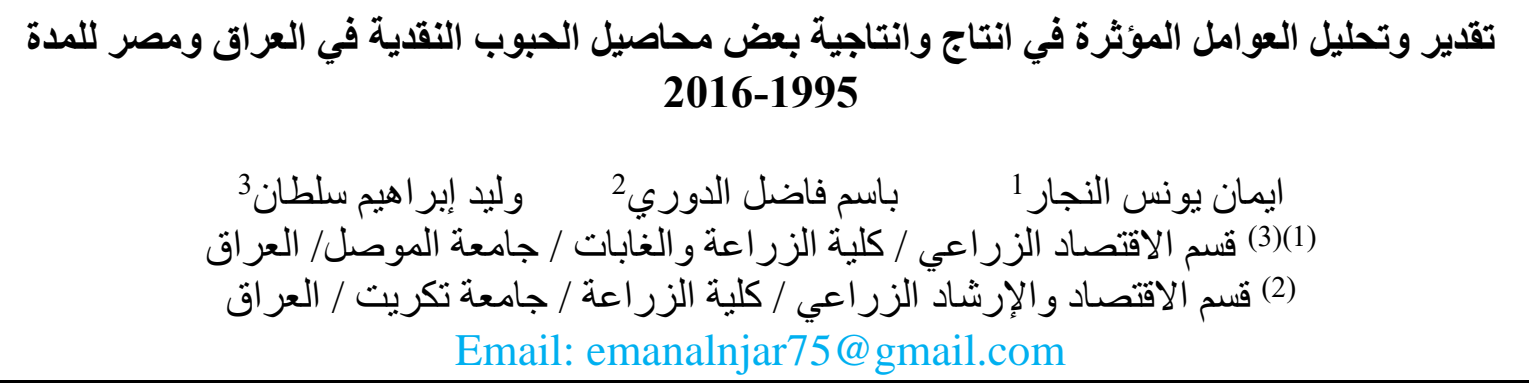

\section{الخلاصة}

يهدف البحث الى تقدير وتحليل العوامل المؤثرة في انتاج وانتاجية محاصيل الحبوب الرئيسة في دولتين عربيتين هي العراق ومصر للمدة 1995- 2016 التي تتسم بانخفاض كمية انتاجها، وقد اختيرت ثلاث انواع منها هي القهح , الشعير , الرز • اعتمد البحث على فرضية مفادها ان هناك تدهورا" في انتاج محاصيل الحبوب تهرب المختارة , لوجود مجموعة عوامل تعيق تطور انتاج هذه المحاصيل خلال المدة 1995 - 2016 ـ ـ لاثبات فرضية البحث, اعتمد في منهجه على اسلوب الربط بين اتجاهين , الاسلوب الوصفي الذي استند الى الدراسات

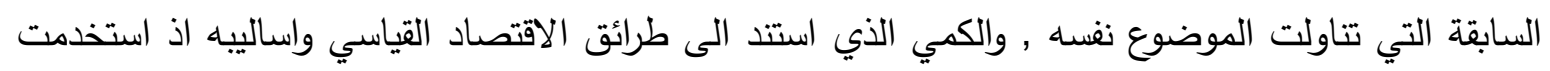

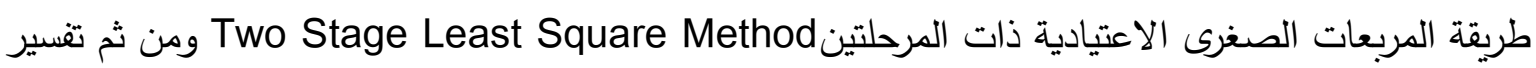
نتائج الاسلوب الكمي لتقييم الجانب التطبيقي من الدراسة بالاعتماد على مفاهيم النظرية الاقتصادية .من الاستتاجات التي تم التوصل اليها خضوع الزراعة في العراق ومصر لعدد من المحددات التي تسهم بتأثيرات متباينة في الحد من نموها. كما اشتمل البحث على اهم النتائج منها ان درجة الانكثاف الاقتصادي الزراعي الاثر السلبي في الكميات المنتجة من محصول الرز في كل من العراق ومصر • وعليه يوصي البحث اتباع سياسة سعرية تسهم في حماية المنتج , جعل الاسعار المحلية للمحاصيل التي تضمنتها الدراسة مقاربة للأسعار

الكلمات المفتاحية: إنتاج الحبوب، إنتاجية الحبوب، العراق , مصر 
تاريخ استلام البحث : 18/ 10/ 2020 ، وقبوله:13 /12 / 2020

\section{REFERENCES}

Al Azzawi, E. Mo. Z. H.( 2011). The Effect of The Agricultural Economic Exposure on The Total Agricultural Output in Selected Arab Countries, M.Sc Thesis, College of Administration and Economics, Mosul University, Iraq .

Al Dulaimi, J. K. (2002). The Future of arab agriculture under the challenges of globalization, Magazine of Economic and Administration Science, College of Administration and Economics, Baghdad University, 9( 30), P:92.

Al Ezzi, S. H. F.( 2000). The Limitations of The Agricultural Labor Productivity in Selected Developing Countries with Special Indication to Iraq, M.Sc Thesis, College of Administration and Economics, Mosul University,Iraq.

Al Najafi, S. T. and E. M. Rashad( 2008) . Are wheat markets non-competitive, Tanmiyat AlRafedain Magazine, College of Administration and Economics, Mosul University, 90( 30), p:74.

Al Najafi, S.T., Q. N. Ghazal and A. W. AlNi'mah( 2010). Politics and the horizons of accomplishing food security: Indices of The Syrian Economy, Tanmiyat AlRafedain Magazine, , College of Administration and Economics, Mosul University, Vol. 32, No. 10 , p:18.

Al Nei'mah, A. W. M.( 2009). The Effect of a number of economic variables on the agricultural added value, A study of A sample of arab countries for the period 1980-2002 in Egypt, Syria and Algeria, Tanmiyat AlRafedain Magazine, College of Administration and Economics, Mosul University, 31(96) , p:7896.

Al Taee, R. S. Q.( 2015). The Trends of the Foreign Agricultural Trade in Selected Developing Countries under the Influence of Contemporary International Economic Variables for the Period 1985-2013, MSc. Thesis, College of Agriculture and Forestry, Mosul University, Iraq.

Al Wasiti, R. T.( 2003). Evaluation of The Agricultural Price Policies of The Cereal Crops in Iraq for The Period 1970-2000, PhD. Thesis, College of Agriculture, Baghdad University, Iraq .

Al Zawbaee, A. A.A.( 1999). Analysis of Prices and The Agricultural Price Policy, $1^{\text {st }}$ Ed., Baghdad Press.

Al-Awadh, E. A.G. (2017). Estimation of Wheat Production Function as Al Jazeerah Project in Sudan For the Period (1990-2014), M.Sc Thesis in applied economics, College of higher studies, Sudan University for Sciences and Technology.

Al-Juboori, G. I. A. (2009). The Effect of The Economic Reform on the Production and Productivity of Wheat in Selected Arab Countries, MSc Thesis, College of Administration and Economics, Mosul University, Iraq .

Al-Mashhadani, A. H., (2018). Economic and Standard analysis of the production and consumption of wheat in Iraq for the period (1990-2014), AlRafedain Agriculture magazine, College of Agriculture and Forestry, Mosul University, 4 (4): 83-91.

Al-Sefou , W. I., (1988). Introduction to Econometrics, College of Administration and Economics, University of Mosul. 
Al-Sefou, W. I., (2006). Fundamentals of Political and Analytical Economics, AlAhlia Publishing, Distribution and Printing - Lebanon.

Anonymous .(2019).The Unified Arab Economic Report .Arab Monetary Fund .

Brawn,E. D. ,A. Iyabode (2020).Determinants of agricultural production and agricultural sector output in Nigeria . Journal of Economics and Management Research. 1(1), 1-9.

Chattha, Muhammad Bilal (2010),Factors affecting wheat yield . A case study of mixed crops zone of the Punjab, Journal of Agricultural research, University of the Punjab , 48(3),p: 403-408.

Food and Agriculture Organization (FAO),(2003). Reports, various Vo.1, for the period (1996-2003).

Kazem, A. H.,(2005) Introduction to Economic Measurement, Zahran Publishing, Baghdad, Iraq.

Kotler , P., Armstrong , G. , Brown, L., and Adam, S.,(2006). Marketing , $7^{\text {th }}$ Ed. Pearson Education Australia/ Prentice Hall .

Mohamed, A., (2006). Analysis of Agricultural Production In Nigeria, Department of Agricultural Economics, and Managing Farms. The University of Horin line 1515 Horin Nigeria 29 Bery p:2.

Raka, Nina, 1994, The Effect of The Total Policies and The Economic Rectification Programs on the Rural Funding Performance, A study submitted in the syposium of the Effect of The Economici rectification (Agricultural Restructure) on the Rural Loaning, Beirut, Lebanon .

Sickles, R. , and Zelenyuk , V., (2019). Measurement of Productivity and Efficiency Theory and Practice, Cambridge, Cambridge University Press .

Singh, H., J. Motwani , A. Kumar (2000) . A review and analysis of the state of the art research on productivity measurement .Industrial Management and Data Systems, Vol.100(3), 34- 41.

United Nation 1987-1988, The Status of Agricultural Foods, A case review in the World and Regions, Changing Priorities in The Fields of Science and Agricultural Technology in The Developing Countries, United Nations Food and Agriculture Organization, Rome ,p:91-92.

United Nation, FAO (2003) "Food Outlook", Food and Agricultural Organization of the U.N, No. (10), Roma .FAO, Yearbook Statistical, (1996-2002)

Yasin ,M.M. , U.R, Farooq (1998). Mechanization of sugarcane production in Pakistan AMA, Agricultural Mechanization in Asia, Africa and Latin America, View Article, Vol. 29, No.1 .p: 37-42 . 